\title{
Analisis Pengaruh Teks Preprocessing Terhadap Deteksi Plagiarisme Pada Dokumen Tugas Akhir
}

\author{
http://dx.doi.org/10.28932/jutisi.v6i3.2892
}

\author{
Ariel Elbert Budiman ${ }^{\# 1}$, Andreas Widjaja ${ }^{\bowtie \# 2}$ \\ \# Program Studi Magister Ilmu Komputer, Fakultas Teknologi Informasi \\ Universitas Kristen Maranatha \\ Jl.Prof. drg. Surya Sumantri No.65, Bandung \\ 11879009 @maranatha.ac.id \\ 2andreas.widjajalit.maranatha.edu
}

\begin{abstract}
Final Project Report at a university has the potential for plagiarism. To detect possible plagiarism, String Similarity can be used. Text preprocessing is needed to process words which can make String Similarity results inaccurate. The value of the distribution of the results of the similarity that is getting higher shows the level of accuracy is also getting higher. Reports that contain many words can make it difficult to find plagiarism recommendations. In this study, we try to divide the report into each chapter to provide more detailed recommendation material. By using text preprocessing and comparison methods in the same chapter, can determine the characteristics of each chapter. The discovery of the characteristics of each chapter can be used as plagiarism recommendation material in more detail than a full-text report. The experiment was a comparison of the results of cosine similarity between the same chapters and full text, then combined with preprocessing stopword removal and stemming. The experimental results show that the use of preprocessing stopword removal and stemming can produce the highest distribution value and the similarity ratio in each chapter can show its characteristics. Words that represent the characteristics of a chapter can potentially become a stopword.
\end{abstract}

Keywords - Chapter Characteristic; Cosine Similarity; Document Preprocessing.

\section{PENDAhUluan}

Plagiarisme merupakan tindakan mengambil ide atau kata dari orang lain tanpa memberi kredit [1]. Plagiarisme menjadi salah satu permasalahan dalam bidang edukasi. Di setiap negara memiliki peraturannya masing-masing terkait ini. Di Indonesia, salah satu peraturan yang mengarah plagiarisme adalah Permendiknas No. 17 tahun 2010 tentang Pencegahan dan Penanggulangan Plagiat di Perguruan Tinggi. Sanksi ditetapkan dari yang paling ringan sampai paling berat. Salah satunya adalah teguran, peringatan tertulis, pembatalan ijazah, pemberhentian tidak dengan hormat dari status mahasiswa.
Walaupun sudah banyak yang menetapkan peraturan dan sanksi, tetap ada kemungkinan mahasiswa melakukan plagiarisme. Salah satu alasan plagiarisme pada mahasiswa salah satunya adalah mereka sedang mengejar waktu [2]. Dikarenakan waktu yang dibutuhkan untuk menyelesaikan studi tidak banyak dengan jumlah pelajaran yang harus dipelajari, mahasiswa terburu-buru mencari nilai agar lolos pada studinya. Dengan adanya internet juga semangkin mudah untuk mengakses informasi dan menyalinnya.

Menurut Jean Liddel [3] ada beberapa poin kenapa mahasiswa melakukan plagiarisme. Pertama, mahasiswa mengira tidak akan ketahuan saat melakukan plagiarisme. Mereka akan cenderung menutupi plagiarisme dengan berbagai cara. Kedua, berusaha sekecil mungkin untuk berhasil melewati mata pelajaran tersebut. Karena kebanyakan dalam system Pendidikan menggunakan tes dan nilai sebagai target kelulusan, maka mahasiswa cenderung fokus untuk mendapatkan nilai yang bagus tanpa melihat usaha dari mahasiswa tersebut.

Penggunaan algoritma String Similarity sudah ada digunakan untuk mendeteksi plagiarisme, salah satu contohnya adalah Leonard dan Hansun [4]. Terdapat bermacam-macam algoritma String Similarity yang dapat digunakan untuk mendeteksi plagiarisme contoh: Rabin Karb Greedy String Tiling, Cosine Similarity, Levenshtein Distance. Setiap algoritma memiliki hasil yang berbeda dan sama juga dengan preprocessing. Contoh preprocessing pada String Similarity pada umumnya adalah stemming dan stopword.

Tanpa preprocessing pada teks, hasil dari kemiripan tidak akurat karena kata umum tidak diolah atau dihilangkan. Karena kata umum pasti ada pada teks laporan, hasil kemiripan akan selalu tinggi. Dengan adanya preprocessing, persebaran angka hasil kemiripan akan membesar. Oleh karena itu akan dianalisis metode preprocessing yang menghasilkan persebaran hasil kemiripan tertinggi.

Pada penelitian ini, algoritma String Similarity Cosine Similarity dengan kombinasi metode preprocessing akan 
digunakan. Lalu dianalisis seberapa besar hasil sebaran nilai perbandingan dari hasil Cosine Similarity menggunakan preprocessing tersebut.

Laporan yang dijadikan sebagai bahan String Similarity memiliki jumlah teks yang besar, sehingga mengetahui petunjuk plagiarisme pada laporan tersebut akan sulit. Untuk mengatasinya, akan dicoba melakukan perbandingan dengan memisahkan setiap bab. Dengan adanya perbandingan per bab, dapat dilakukan analisis terhadap karakteristik pada setiap bab.

Hipotesis dari penelitian ini adalah sebagai berikut:

1) Metode Preprocessing Stopword + Stemming menghasilkan sebaran nilai similarity $(\cos \theta)$ paling tinggi daripada metode tanpa Preprocessing, Stopword, dan Stemming.

2) Menggunakan metode perbandingan bab menghasilkan tingkat similarity lebih besar daripada full text.

\section{KAJIAN TEORI}

\section{A. String Plagiarism Detection Document Based}

Untuk mendeteksi potensi terjadinya plagiarisme dapat membandingkan karya pada pasangan orang. Dalam dunia akademik, karya yang sering menjadi target plagiarisme merupakan tugas mahasiswa yang berbentuk teks dokumen. Untuk mencari pelaku plagiarisme, dosen akan membandingkan satu per satu pasangan dokumen yang dibuat oleh mahasiswa. Salah satu cara untuk membandingkan adalah dengan melihat kemiripan teks pasangan dokumen tersebut. Namun cara tersebut menghabiskan banyak waktu tergantung dari seberapa banyak teks yang harus dibandingkan dan jumlah mahasiswa, dan akurasi untuk mendeteksi terjadinya potensi plagiarisme disesuaikan dengan keinginan dosen tersebut. Sehingga hasilnya deteksi plagiarisme tidak akurat dan tidak efisien.

Salah satu upaya untuk mendeteksi plagiarisme yaitu menggunakan program untuk mengecek kemiripan teks. Berbagai program untuk mendeteksi plagiarisme telah dibuat, misalnya [5], [6], [7], [8], dan [9]. Dalam [7] melakukan deteksi plagiarisme dengan penambahan metode text preprocessing. Teks preprocessing yang dilakukan adalah tokenization, stopword removal, dan stemming. Graham dan Starr [9] melakukan survey pada mahasiswa dan staff mengenai penggunaan Turnitin. Turnitin merupakan sistem deteksi plagiarisme yang dipakai oleh 26 juta mahasiswa dan instruktur pada tahun 2014 [10]. Fungsionalitas utama dari Turnitin adalah melakukan perbandingan konten dengan jurnal yang telah diserahkan dan disimpan dalam database milik Turnitin. Dalam survey nya yang menggunakan Bristol Online Survey service menunjukan bahwa sebanyak 266 (72.5\%) mahasiwa mengenali Turnitin dan 101 (27.5\%) mahasiswa tidak. Pada Staff sebanyak 61 (98.4\%) Staff mengenali Turnitin dan 1 (1.6\%) Staff tidak. Dalam Turnitin tidak menetapkan plagiarisme berdasarkan persentase threshold. Melainkan,
Turnitin akan melakukan highlight pada urutan teks yang sama pada paper yang lainnya sebagai bahan rekomendasi plagiarisme. Berdasarkan Fudge [11], angka threshold dalam menentukan plagiarisme tidak dapat ditentukan dengan sebuah angka. Karena terlalu banyak variabel yang perlu ditentukan seperti cara teknis mahasiwa melakukan plagiarisme dan akurasi detection tools.

Tokenization adalah proses memisahkan string teks menjadi bagian bagian yang disebut dengan token [12]. Kumpulan token yang memiliki karakter yang sama disebut dengan type. Type yang sudah dinormalisasikan disebut dengan term. Untuk pemotongan teks, dapat melakukan pemotongan teks pada seluruh karakter yang bukan alfanumerik. Cara ini dapat dilakukan pada teks yang berbahasa Indonesia. Untuk Bahasa Indonesia dapat diperlengkap dengan menambahkan karakter "/" dan "_.". Namun, tidak seluruh Bahasa dapat menggunakan cara ini, contohnya adalah Bahasa Jepang.

Stopword merupakan kata yang sering muncul. Dalam Information Retrieval dan text mining, stopwords tidak begitu terpakai karena tidak membawa informasi [12], contohnya adalah kata sambung seperti "untuk", "di", "atau", "dari”, dll. Fungsi utamanya dari pembuangan stopwords adalah mencegah agar stopwords tidak mempengaruhi hasil pada proses selanjutnya.

Stemming dalam information retrieval merupakan prosedur untuk mengurangi seluruh kata yang memiliki kata dasar yang sama. Biasanya dilakukan pemotongan pada imbuhan untuk menjadi kata dasar [13]. Salah satu algoritma yang digunakan untuk proses stemming Bahasa Indonesia dibuat oleh Tala [14].

Contoh hasil teks preprocessing dapat dilihat pada Tabel I.

TABEL I

CONTOH HASIL PREPROCESSING

\begin{tabular}{|l|l|}
\hline Metode & Teks \\
Tanpa & $\begin{array}{l}\text { seiring dengan perkembangan zaman, } \\
\text { teknologi pun berkembang semakin } \\
\text { pesat. Dengan adanya perkembangan } \\
\text { teknologi tersebut, informasi dapat } \\
\text { diperoleh dengan lebih efisien dan } \\
\text { efektif. Selain itu, perkembangan } \\
\text { teknologi juga membuat banyak } \\
\text { organisasi menggunakan sistem yang } \\
\text { terkomputerisasi, agar informasi dapat } \\
\text { diperoleh dengan cepat. Selain itu, } \\
\text { komputerisasi juga dapat } \\
\text { meminimalisirkan human error yang } \\
\text { sering terjadi }\end{array}$ \\
\hline Tokenization & $\begin{array}{l}\text { seiring;dengan;perkembangan;zaman;; } \\
\text { eknologi;pun;berkembang;semakin;pes } \\
\text { at;Dengan;adanya;perkembangan;tekno } \\
\text { logi;tersebut;informasi;dapat;diperoleh; } \\
\text { dengan;lebih;efisien;dan;efektif;Selain;i }\end{array}$ \\
\hline
\end{tabular}




\begin{tabular}{|l|l|}
\hline Metode & Teks \\
\hline $\begin{array}{l}\text { tu;perkembangan;teknologi;juga;memb } \\
\text { uat;banyak;organisasi;menggunakan;sis } \\
\text { tem;yang;terkomputerisasi;agar;informa } \\
\text { si;dapat;diperoleh;dengan;cepat;Selain;i } \\
\text { tu;komputerisasi;juga;dapat;meminimal } \\
\text { isirkan;human;error;yang;sering;terjadi; }\end{array}$ \\
\hline Stemming & $\begin{array}{l}\text { iring;dengan;kembang;zaman;teknologi } \\
\text {;pun;kembang;makin;pesat;dengan;ada; } \\
\text { kembang;teknologi;sebut;informasi;dap } \\
\text { at;oleh;dengan;lebih;efisien;dan;efektif; } \\
\text { selain;itu;kembang;teknologi;juga;buat; } \\
\text { banyak;organisasi;guna;sistem;yang;ko } \\
\text { mputerisasi;agar;informasi;dapat;oleh;d } \\
\text { engan;cepat;selain;itu;komputerisasi;ju } \\
\text { ga;dapat;meminimalisirkan;human;erro } \\
\text { r;yang;sering;jadi }\end{array}$ \\
\hline $\begin{array}{l}\text { Stopword } \\
\text { Removal }\end{array}$ & $\begin{array}{l}\text { iring;kembang;zaman;teknologi;kemba } \\
\text { ng;pesat;kembang;teknologi;informasi; } \\
\text { efisien;efektif;kembang;teknologi;organ } \\
\text { isasi;sistem;komputerisasi;informasi;ce } \\
\text { pat;komputerisasi;meminimalisirkan;hu } \\
\text { man;error }\end{array}$ \\
\hline
\end{tabular}

Sesudah text preprocessing dilakukan pada kedua dokumen, algoritma string similarity akan dijalankan. Beberapa algoritma String Similarity telah diimplementasikan untuk deteksi plagiarisme. Dalam [7], menggunakan algoritma Rabin Karb Greedy String Tiling (RKRGST) untuk pengecekan String Similarity pada datanya. Sulistiani dan Karnalim [8] menggunakan Cosine Similarity dan alternative algoritma yang lain RKRGST, Local Alignment dan Local Alignment with cosine-based filtering.

\section{B. Cosine Similarity}

Algortma cosine similarity sering digunakan untuk mengukur kemiripan (similarity) antara dua dokumen. Kedua dokumen direpresentasikan sebagai vektor-vektor, yang disebut sebagai vektor-vektor dokumen [15]. Similarity kedua dokumen dihitung dari normalisasi dot product dari kedua vektor tersebut, yang sama dengan kosinus sudut yang dibentuk oleh kedua vektor dokumen tersebut, seperti pada persamaan (1) berikut ini:

$$
\cos \theta=\operatorname{sim}(x, y)=\frac{x \cdot y}{\|x\|\|y\|}
$$

Dimana $\|x\|$ merupakan Euclidian norm dari vektor $\quad x=\left(x_{1}, x_{2}, \ldots, x_{p}\right), \quad$ yaitu $\quad\|x\|=$ $\sqrt{x_{1}^{2}+x_{2}^{2}+\ldots+x_{p}^{2}}$, yang disebut juga sebagai "Panjang" vektor [16]. Begitu pula dengan $\|y\|$ merupakan Euclidian norm dari vektor $y$. Nilai $\cos \theta$ yang semangkin mendekati 1 atau semakin kecil sudutnya berarti kedua vektor tersebut semakin mirip. Sebaliknya apabila nilai $\cos \theta$ semangkin mendekati 0 berarti kedua vektor semakin tidak mirip.

\section{Pembuatan Vektor Dokumen}

Pertama, query akan menghasilkan term dari dokumen dimana term merupakan setiap katanya [15]. Berikutnya setiap term ditentukan nilai weight, total kemunculan term dari dokumen tersebut. Cara pemberian weight ini dapat disebut juga dengan term frequency. Setelah melakukan term frequency pada seluruh term, diurutkan dan menjadi model bag of words. Pada titik ini, dokumen "halo salam kenal" dengan dokumen "salam kenal halo" merupakan dokumen yang sama karena memiliki term frequency yang sama.

Dari kumpulan term frequency dari sebuah dokumen, nilai setiap term frequency diubah menjadi satu komponen vektor. Lalu setiap term dari kumpulan term dari dokumen merepresentasikan satu axis dalam vector space.

\section{TINJAUAN PUSTAKA}

Dalam penelitian ini, sistem deteksi plagiarisme laporan tugas akhir menggunakan Cosine Similarity dan juga mencari kombinasi teks preprocessing yang sesuai untuk sistemnya. Ada beberapa penelitian yang mendukung dalam pembuatan sistem deteksi plagiarisme dan analisis teks preprocessing.

Parwitta, Indradewi, dan Wijaya [7] membuat sistem deteksi plagiarisme menggunakan Rabin Karp Hashing pada Hash. Lalu menggunakan algoritma Dice's Similarity Coefficients untuk mengecek kemiripannya. Untuk preprocessingnya menggunakan Tokenization, Stopwords dan stemming. Penelitian ini merupakan dasar penelitian yang dipakai.

Mardiana, Adji, dan Hidayah [17] melakukan analisis pengaruh Stemming pada Similarity Detection pada Bahasa Indonesia. Hasilnya menunjukan bahwa penggunaan stemming dan stopwords memiliki presisi yang lebih besar pada yang menggunakan stemming saja dan tanpa preprocessing. Pada fourgram penggunaan stemming dan stopwords menghasilkan persentase $67 \%$ sedangkan yang lain hanya sekitar $30 \%$. Pada penelitian ini menunjukan adanya hasil dari penggunaan Stemming dan stopword pada abstract. Hasilnya dapat dijadikan kerangka penelitian namun menggunakan data yang lebih besar yaitu keseluruhan isi laporan.

Sulistiani dan Karnalim [8] membuat sistem deteksi plagiarisme dengan beberapa alternative metode String Similarity. Metode yang digunakan adalah Rabin Karb 
Greedy String Tiling (RKRGST), Cosine Similarity, Local alignment dan Local alignment with cosine-based filtering. Dari ke empat metode tersebut, RKRGST memiliki deteksi yang efektif namun memiliki waktu proses yang sangat lama.

Karena data yang akan digunakan berupa dokumen maka pada penelitian yang akan dilakukan ini perlu menggunakan Cosine Similarity. Dalam dokumen memiliki banyak teks, sehingga perlu difokuskan dalam kecepatan komputasinya dan Cosine Similarity memiliki komputasi yang cepat dalam teks yang banyak.

\section{IV.IMPLEMENTASI PENELITIAN}

\section{A. Implementasi Preprocessing Data}

Data yang digunakan berupa laporan Tugas Akhir berbahasa Indonesia dari sebuah universitas sebanyak 24 data. Format dari laporan tersebut berbentuk file PDF yang terbagi setiap bab.

File PDF tersebut di ubah menjadi teks agar dapat digunakan oleh String Similarity. Untuk pengubahan file pdf menjadi teks menggunakan algoritma Optical Character Recognition (OCR). Fungsi dari OCR untuk mengubah file gambar yang berisi tulisan menjadi file teks.

File PDF pertama akan diubah dulu menjadi gambar dalam bentuk format .jpg. Setiap file akan iterasi setiap halaman menjadi satu .jpg. Lalu setiap gambar diubah menjadi teks dengan bantuan library pytesseract [18]. Python-tesseract (pytesseract) merupakan Optical Character Recognition tool untuk python. Library ini dapat mengenali dan mengubah menjadi teks dari gambar.

\section{B. Implementasi algoritma Cosine Similarity}

File yang sudah diubah menjadi teks diproses kembali. Sistem akan mengambil dua dokumen untuk dibandingkan dengan Cosine Similarity. Proses Cosine Similarity menggunakan bantuan library sklearn [19]. Teks diubah menjadi vektor berupa matriks yang berisi token jumlah dari jenis kata dengan bantuan CountVectorizer [20]. Lalu vektor tersebut

Selanjutnya untuk perbandingan menggunakan dua cara yaitu dengan per bab (A) atau seluruh bab (B). Pada metode perbandingan per bab akan dibandingkan pada bab yang sama dengan pasangannya.

Untuk preprocessing teks akan dikombinasi metode perbandingan bab dengan 3 cara: tanpa preprocessing (Z), Stopword Removal (S) dan Stemming (ST). Lalu sesudah dua dokumen sudah selesai preprocessing teks akan dibandingkan dengan cosine similarity. Program dengan kombinasi metode akan dijalankan secara terpisah. Proses Stopword Removal menggunakan library nltk [21] stopwords yang Bahasa Indonesia. Natural Language Toolkit (nltk) merupakan platform untuk membuat program Python dapat bekerja dengan data bahasa manusia. Nltk memiliki fitur text processing untuk classification, tokenization, stemming, tagging, parsing, semantic reasoning. Sedangkan pada proses Stemming menggunakan library Sastrawi [22] yaitu library Stemming untuk Bahasa Indonesia. Library ini menggunakan Algoritma Stemming dari Nazief dan Adriani [23] untuk Bahasa Indonesia. Kata dasar yang dipakai berdasarkan data kamus kata dasar dari kateglo.com dengan sedikit perubahan.

\section{TABEL II}

KOMBINASI METODE PREPROCESSING

\begin{tabular}{|c|c|c|c|c|c|}
\hline & \multicolumn{5}{|c|}{ Metode Preprocessing } \\
\hline & Z & S & ST & STS & SST \\
\hline $\begin{array}{c}\text { Per Bab } \\
\text { (A) }\end{array}$ & AZ & AS & AST & ASTS & ASST \\
\hline $\begin{array}{c}\text { Seluruh } \\
\text { Bab(B) }\end{array}$ & BZ & BS & BST & BSTS & BSST \\
\hline
\end{tabular}

Tabel II merupakan kombinasi metode yang akan dilakukan untuk eksperimen. Pada metode Per Bab (A) akan dibandingkan bab yang sama dengan pasangannya, contoh: ID1_Chapter1 dengan ID2_Chapter1. Sedangkan metode Seluruh Bab (B), teks pada setiap bab digabungkan menjadi satu teks. Lalu teks gabungan tersebut di bandingkan dengan teks gabungan lainnya. Setiap metode A dan B dikombinasikan dengan metode preprocessing tanpa preprocessing (Z), stopword removal (S), stemming (ST), stemming + stopword removal (STS) dan stopword removal + stemming (SST).

Kode Program 1. Pseudo Code Cosine Similarity

def cosine_simimlarity $(\mathrm{a}, \mathrm{b})$ : return float $(\operatorname{dot}(a, b) /(\operatorname{norm}(a) * \operatorname{norm}(b)))$

Pada Kode Program 1 menunjukan cara menghitung Cosine Similarity. Variabel a dan b merupakan vektor berupa list dari angka. Fungsi dot(a,b) akan melakukan dot product pada vektor a dan b. Fungsi norm(a) berupa Euclidean norm dari vektor a, yaitu $\|a\|=$ $\sqrt{a_{1}^{2}+a_{2}^{2}+\ldots+a_{p .}^{2}}$. Begitu pula sama dengan vektor $\mathrm{b}$ pada $\operatorname{norm}(\mathrm{b})$.

Kode Program 2. Cosine Similarity pada Per Bab

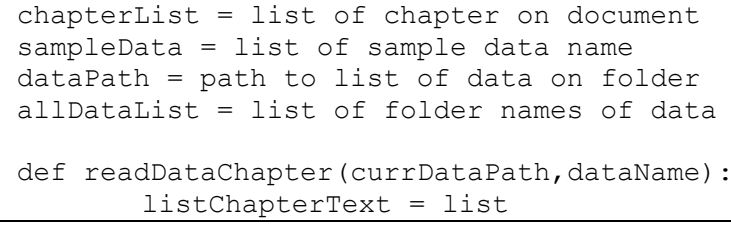




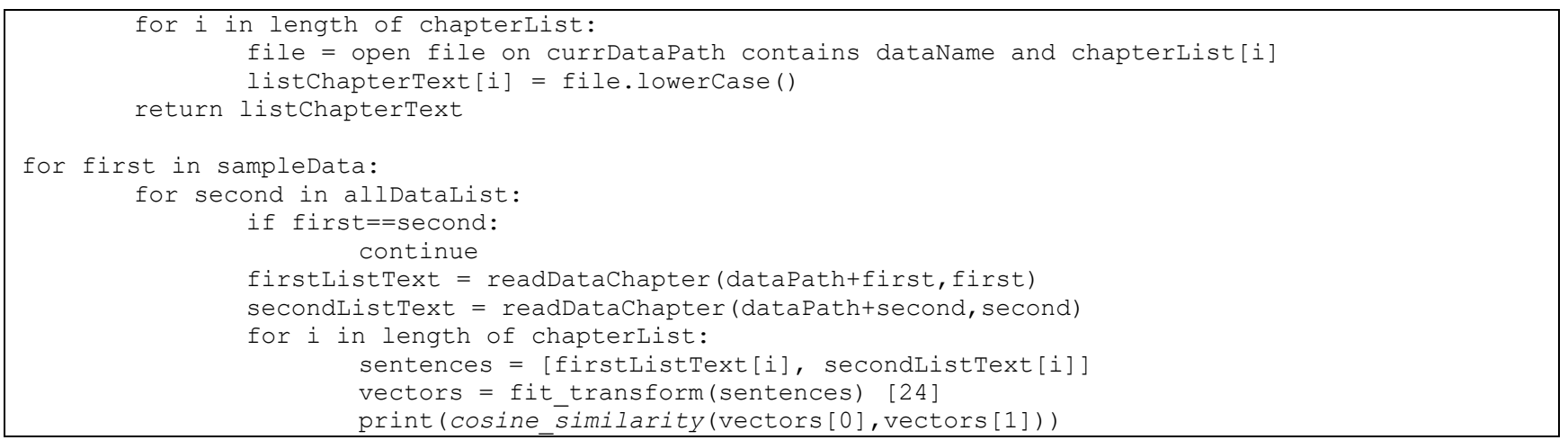

\section{Kode Program 3. Cosine Similarity pada Full Text}

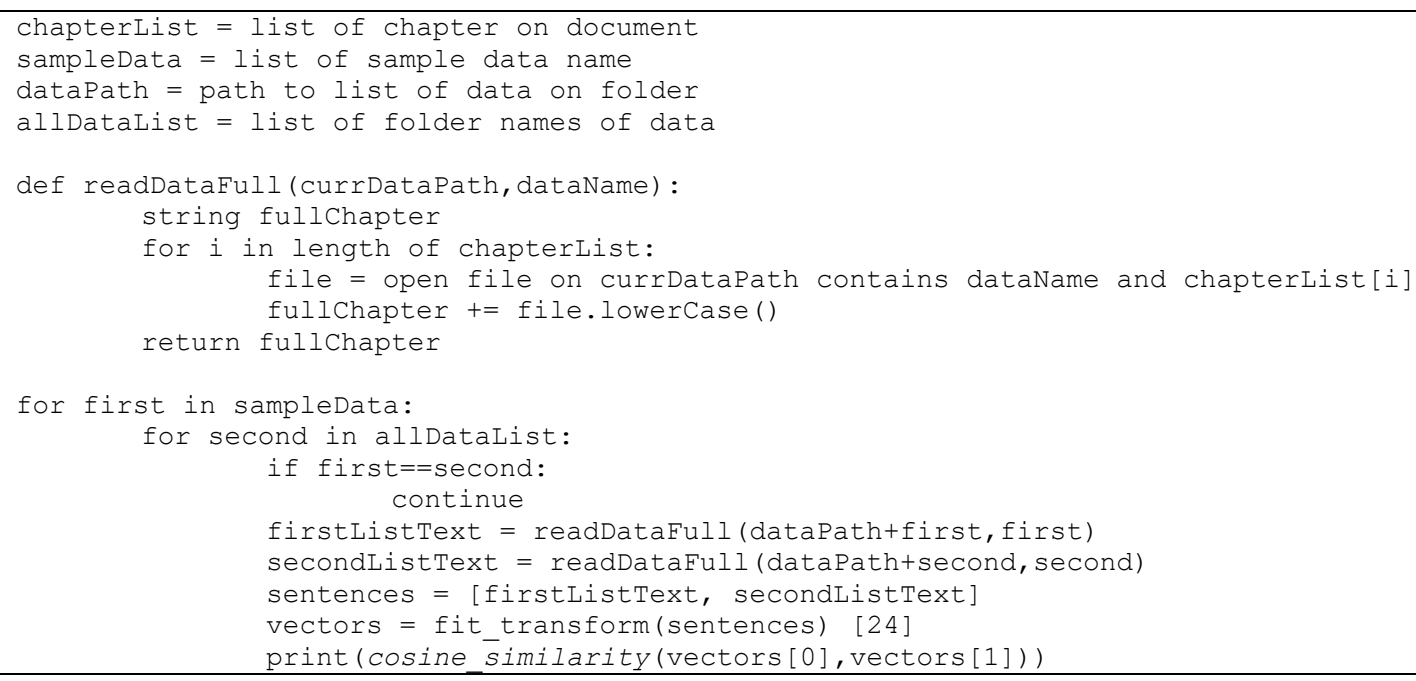

Variabel chapterList merupakan list nama bab yang akan dipakai untuk dibandingkan pada laporan tersebut. Variabel sampleData berisi list sampel laporan yang akan dibandingkan dengan seluruh laporan. Variabel dataPath berisi folder path seluruh data laporan Tugas Akhir. Variabel allDataList berisi list nama folder seluruh data laporan Tugas Akhir.

Pada Kode Program 2 dan Kode Program 3 terdapat function read data hasil txt dari algoritma OCR pada data laporan. Function readDataChapter menghasilkan list dari string teks setiap bab sedangkan pada readDataFull menghasilkan gabungan teks seluruh bab menjadi satu string.

Untuk perhitungan perbandingan laporan menggunakan algoritma Cosine Similarity. Pertama, list sampleData dibandingkan dengan list allDataList tanpa membandingkan laporan yang sama. Pada Kode Program 2, akan dilakukan iterasi pada setiap bab yang terdaftar pada chapterList. Teks bab firstListText dan secondListText dimasukan pada variabel sentences yang akan dilakukan mapping kamus kata menggunakan fungsi fit_transform [24] dari library
CountVectorizer menghasilkan list vektor dua laporan berdasarkan kamus kata tersebut. Lalu vektor akan dihitung nilai perbandingannya menggunakan cosine_similarity pada Kode Program 1 [25] dari library nltk.

\section{Pembuatan Eksperimen}

Data yang diuji coba sebanyak 24 data laporan Tugas Akhir program studi teknologi informasi pada sebuah universitas. Setiap data teks laporan tersebut diberi nama Mxx, dimana $\mathrm{M}$ merupakan penamaan data teks dan $\mathrm{x}$ merupakan nomor data teks mahasiswa. Sehingga terdapat data teks M01 hingga M024.

Lalu dilakukan 3 kali eksperimen dengan data yang berbeda. File teks yang digunakan yaitu: ID_Chapter1.pdf, ID_Chapter2.pdf, ID_Chapter3.pdf, ID_Chapter4.pdf, ID_Chapter5.pdf, dan ID_Conclusion.pdf. Total perbandingan yang dilakukan: 23 (Perbandingan tanpa dengan ID yang sama) x 3 (Case) x 10 (Metode) $=690$ perbandingan. Gambaran eksperimen tersebut dapat dilihat pada Gambar 1. 


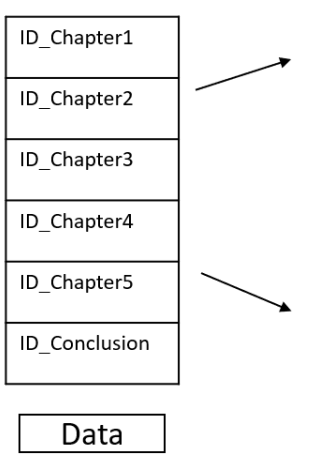

Data

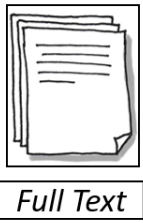

$$
\begin{array}{|l|}
\hline \text { 1. Tanpa Preprocessing } \\
\text { 2. Stopword Removal } \\
\text { 3. Stemming } \\
\text { 4. Stopword Removal + Stemming } \\
\text { 5. Stemming + Stopword Removal } \\
\quad \text { Kombinasi Preprocessing } \\
\hline
\end{array}
$$

\section{Kombinasi Preprocessing}

1. Tanpa Preprocessing

2. Stopword Removal

3. Stemming

4. Stopword Removal + Stemming

5. Stemming + Stopword Removal

Kombinasi Preprocessing

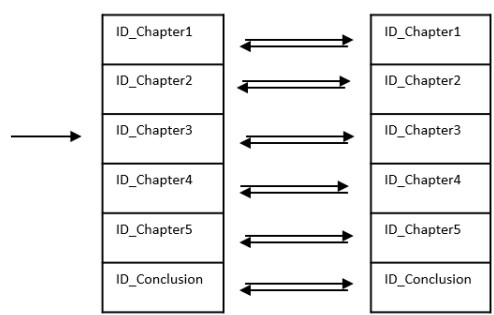

Cosine Similarity

Gambar 1. Metodologi Penelitian

\section{HASIL PENELITIAN}

\section{A. Penjelasan Hipotesis}

Berdasarkan hasil yang didapatkan, terdapat hipotesis sebagai bahan rekomendasi metode yang digunakan untuk program deteksi plagiarisme.
1) Metode preprocessing kata efektif digunakan apabila berhasil membuat nilai perbandingan mempunyai persebaran yang lebih besar. Contoh: $\mathrm{Z}$ merupakan hasil perbandingan dengan metode tanpa preprocessing, dan $\mathrm{X}$ dengan metode preprocessing. Gambar 2 merupakan contoh grafik dari perbandingan data teks seorang mahasiswa (A1) dengan data teks mahasiswa yang lainnya (A2-A6, karena data teks mahasiswa A1 tidak dibandingkan dengan dirinya sendiri) dengan metode $\mathrm{Z}$ dan $\mathrm{X}$.

\section{Perbandingan data teks A1 dengan A2-A6}

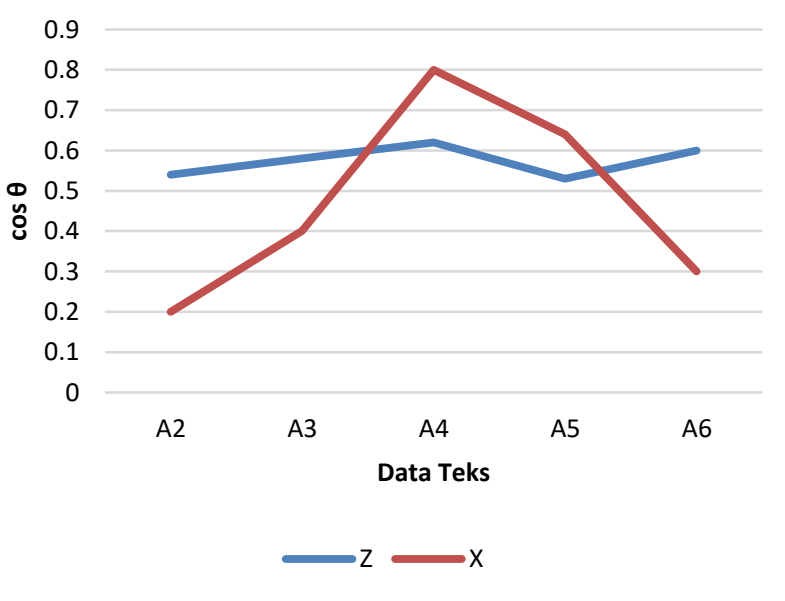

Gambar 2 Contoh Grafik Hipotesis PertamaAnalisis Hasil Dengan Hipotesis Pertama 
2) Nilai similarity pada perbandingan full text akan selalu lebih besar dengan nilai similarity pada perbandingan setiap bab yang sama.

\section{B. Analisis Hasil Dengan Hipotesis Pertama}

Pada eksperimen pertama menggunakan data perbandingan ID M03 dengan seluruh ID yang lain menghasilkan Gambar 3 - Gambar 9. Untuk menghitung persebaran pada hasil kemiripan pada laporan, digunakan nilai standar deviasi dari hasil kemiripan kombinasi metode.

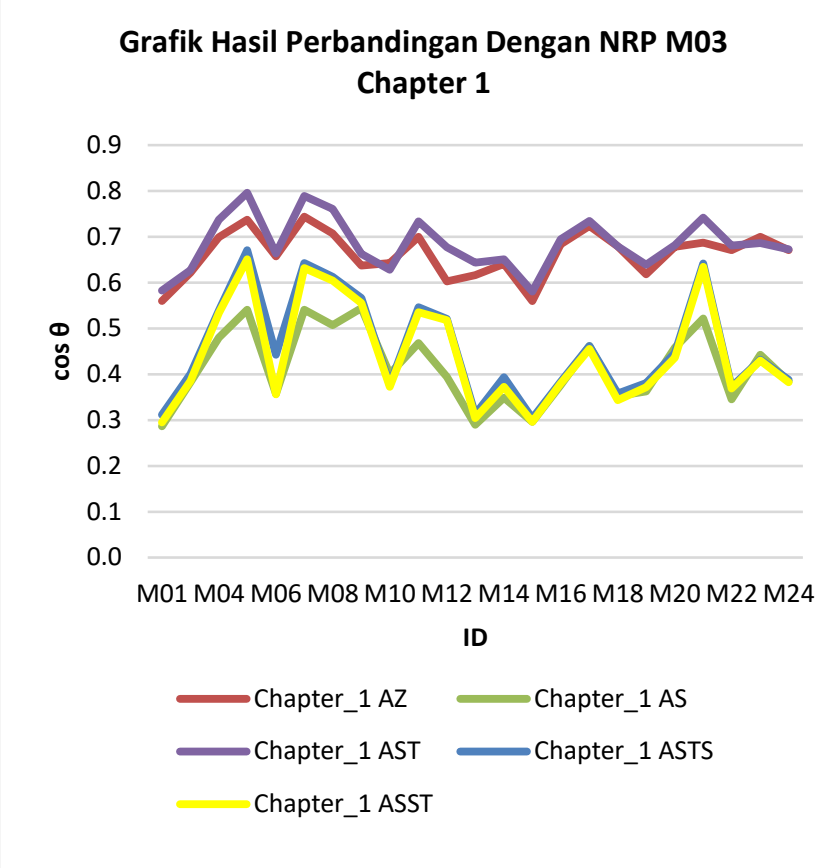

Gambar 3 Grafik Hasil Perbandingan Dengan ID M03 Chapter 1

Pada Gambar 3, metode AZ dengan AST tidak memiliki perbedaan yang signifikan. Metode AS, ASTS, dan ASST juga tidak memiliki perbedaan yang signifikan namun secara kesuluruhan nilai perbandingannya $(\cos \theta)$ menurun.

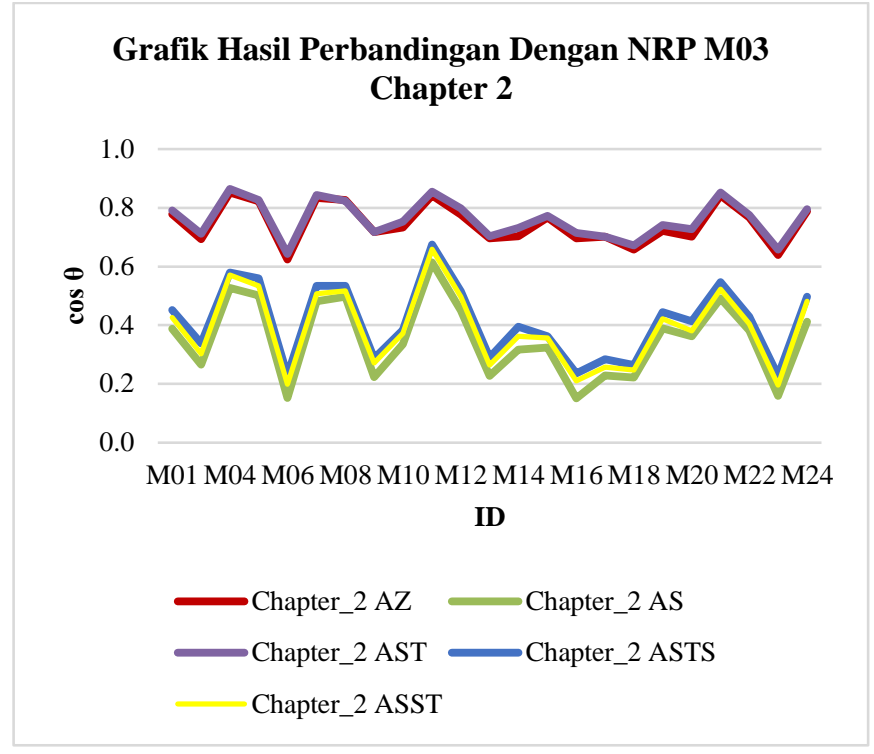

Gambar 4 Grafik Hasil Perbandingan Dengan ID M03 Chapter 2

Pada Gambar 4, hasilnya memiliki pola yang sama dengan Gambar 3. Metode AZ dengan AST tidak memiliki perbedaan yang signifikan. Metode AS, ASTS, dan ASST juga tidak memiliki perbedaan yang signifikan namun secara kesuluruhan nilai perbandingannya $(\cos \theta)$ menurun.

\section{Grafik Hasil Perbandingan Dengan NRP M03 Chapter 3}

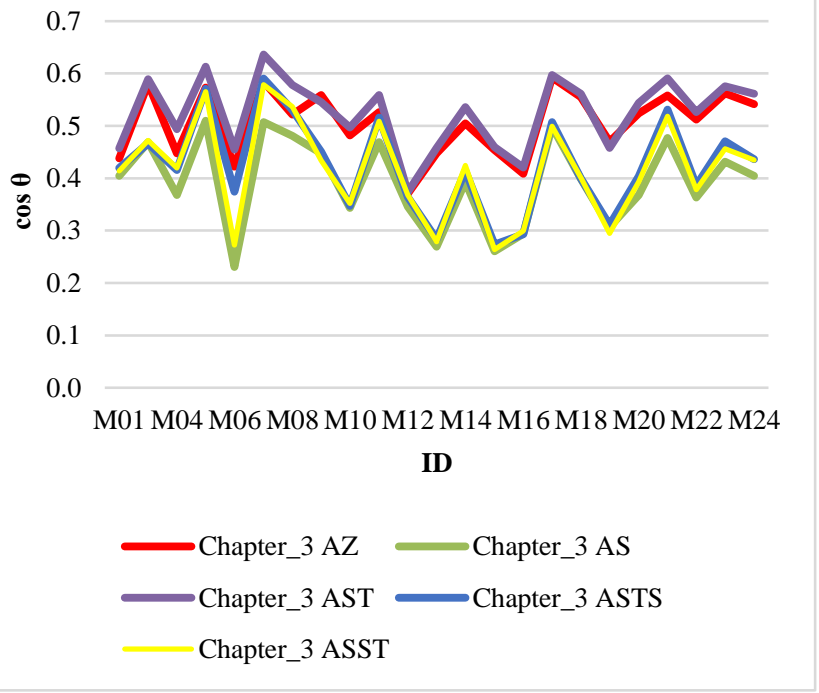

Gambar 5 Grafik Hasil Perbandingan Dengan ID M03 Chapter 3

Pada Gambar 5, memiliki pola yang berbeda dengan Gambar 3 dan Gambar 4. ID M04 - M06, M10, dan M22 seluruh metode nya tidak menghasilkan perbedaan $\cos \theta$ yang signifikan. Namun secara kesuluruhan metode AZ dan 
AST menghasilkan $\cos \theta$ yang lebih tinggi dari metode AS, ASTS, dan ASST.

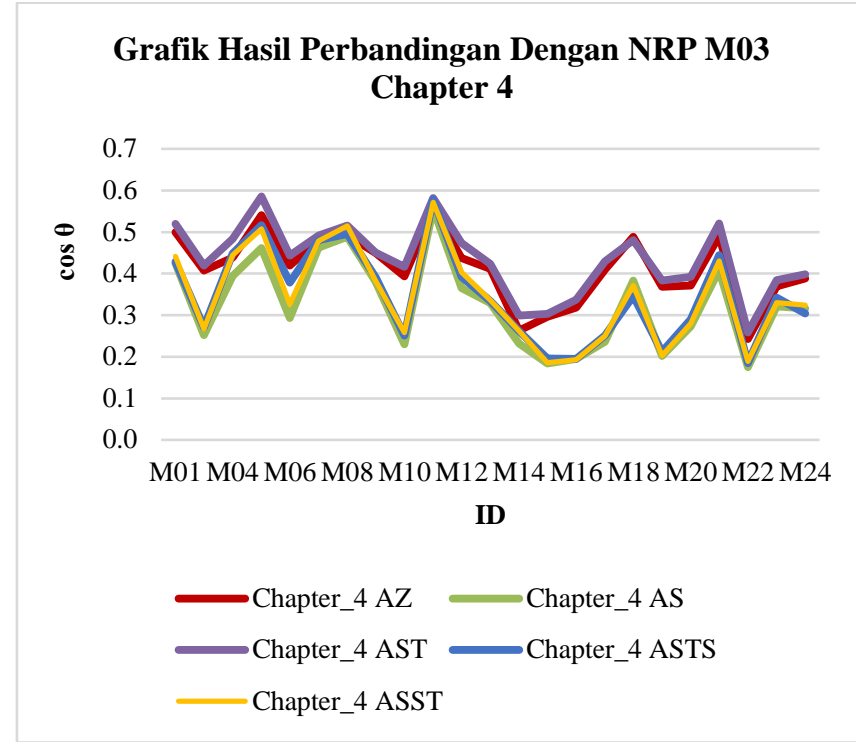

Gambar 6 Grafik Hasil Perbandingan Dengan ID M03 Chapter 4

Gambar 6 menunjukkan metode AZ dan AST dengan AS, ASTS, dan ASST di Chapter 4 tidak memiliki perbedaan yang signifikan. Setelah ditelusuri, data teks pada Chapter 4 memiliki campuran antara teks Bahasa Indonesia dan Bahasa Inggris. Berdasarkan seluruh data, Chapter 4 cenderung memiliki teks kode program. Karena preprocessing yang dilakukan hanya pada teks Bahasa Indonesia, perbedaan nilai similarity yang dihasilkan tidak signifikan.

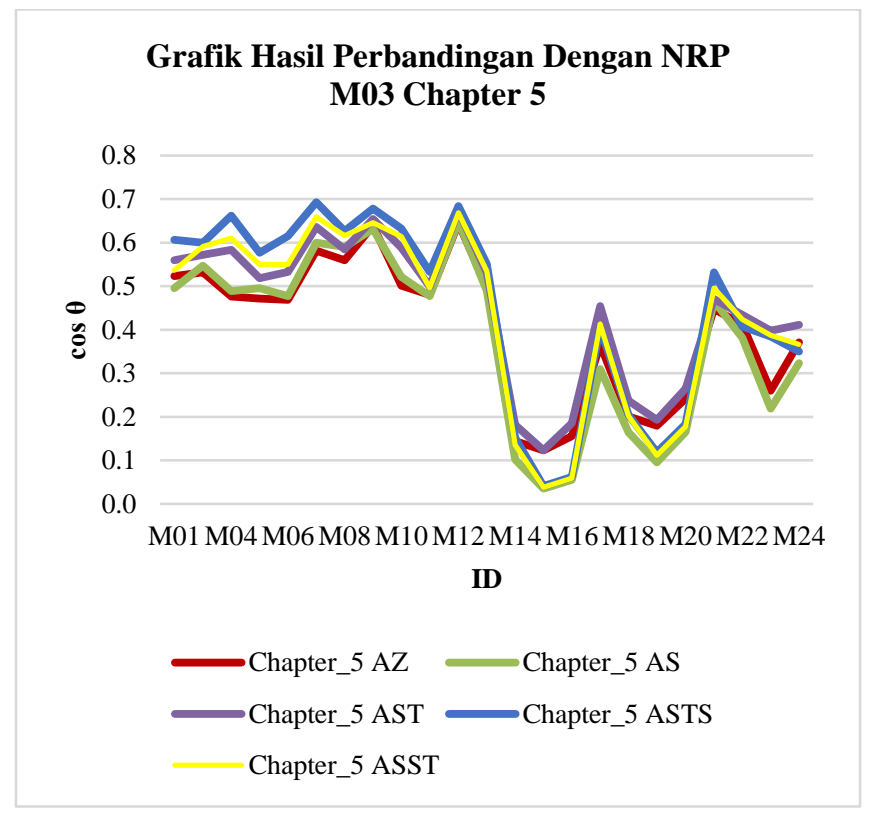

Gambar 7 Grafik Hasil Perbandingan Dengan ID M03 Chapter 5
Berdasarkan Gambar 7, terdapat penurunan nilai kemiripan pada ID M13. Setelah ditelusuri, ID M01 hingga M12 termasuk ID M03 memiliki format laporan yang sama pada Chapter 5. Sedangkan ID M14 hingga M24, menggunakan format yang berbeda beda sehingga menghasilkan nilai $\cos \theta$ yang bervariasi.

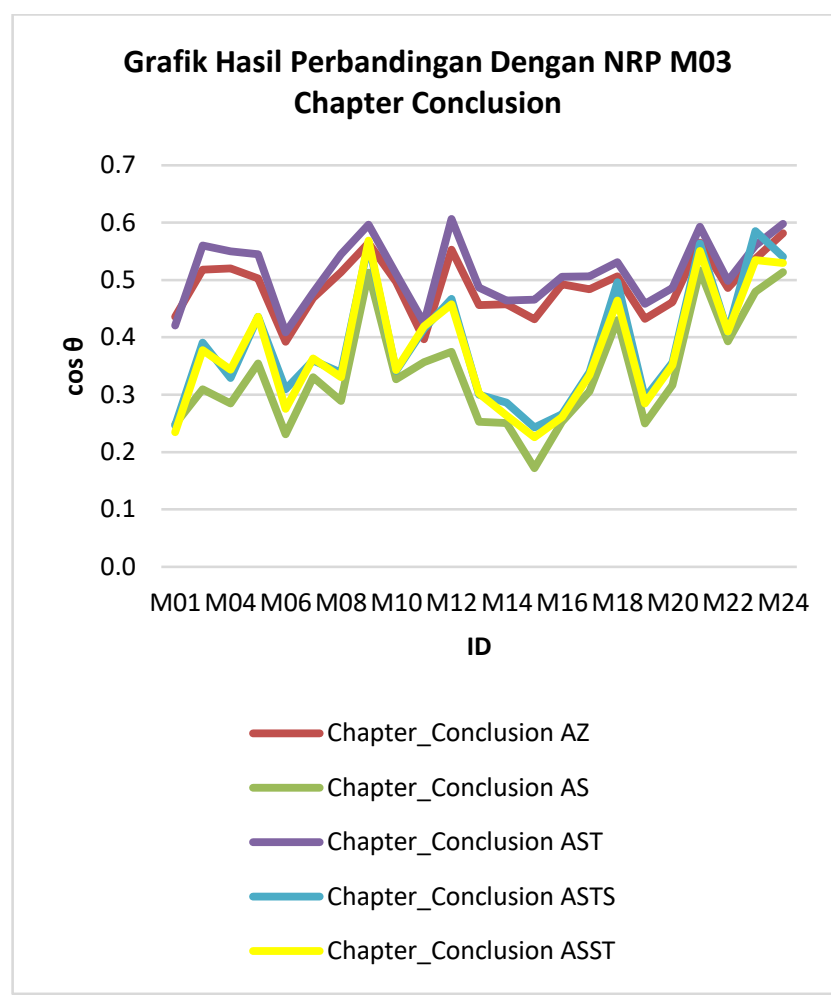

Gambar 8 Grafik Hasil Perbandingan Dengan ID M03 Chapter Conclusion

Berdasarkan Gambar 8, metode AZ dan AST dengan AS, ASTS, dan ASST memiliki perbedaan yang cukup signifikan. Namun pada perbandingan ID M08, M18 dan M22 tidak memiliki perbedaan yang signifikan. 


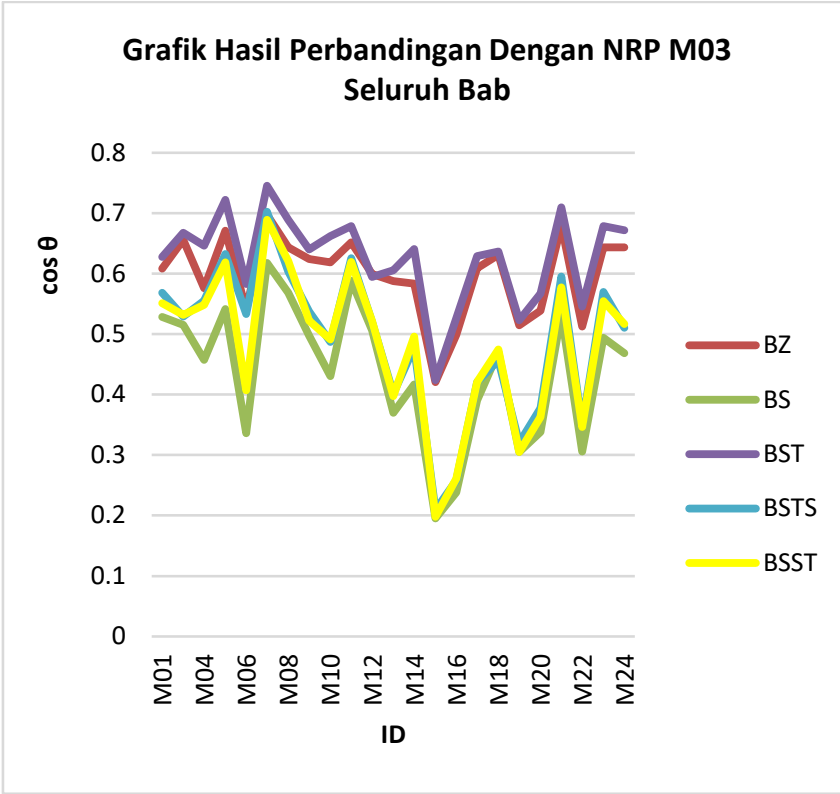

Gambar 9 Grafik Hasil Perbandingan Dengan ID M03 Seluruh Bab

Berdasarkan Gambar 9, metode AZ dan AST dengan AS, ASTS, dan ASST memiliki perbedaan yang cukup signifikan.

Berdasarkan Gambar 3 hingga Gambar 9, metode AZ dan AST menghasilkan nilai $\cos \theta$ yang mirip. Lalu metode AS, ASTS, dan ASST menghasilkan nilai $\cos \theta$ yang lebih rendah dari AZ dan AST. Nilai $\cos \theta$ pada metode AS, ASTS, dan ASST tidak memiliki perbedaan yang signifikan.

TABEL III

JuMLAH STANDAR DEVIASI TERTINGGi DARI 3 EKSPERIMEN

\begin{tabular}{|c|c|c|c|c|c|c|}
\hline No & ID & Z & S & ST & STS & SST \\
\hline 1 & M03 & 0 & 1 & 0 & 3 & 3 \\
\hline 2 & M11 & 0 & 4 & 0 & 1 & 2 \\
\hline 3 & M21 & 0 & 4 & 0 & 3 & 0 \\
\hline & Total & 0 & 9 & 0 & 7 & 5 \\
\hline
\end{tabular}

Tabel III merupakan hasil penjumlahan nilai Standar Deviasi tertinggi dari perbandingan nilai similarity 3 eksperimen dengan kombinasi preprocessing. Berdasarkan Tabel III, dari tiga eksperimen dengan ID M03, M11, dan M21 metode S memiliki total Standar Deviasi Tertinggi. Namun, penggabungan preprocessing stopword removal dengan stemming memiliki jumlah total yang lebih besar dari metode stopword. Untuk menguji seberapa besar pengaruh urutan preprocessing stopword removal dan stemming, dapat menggunakan uji signifikansi dengan TTest. Untuk nilai keyakinan / Alpha yang ditetapkan sebesar 0.05 atau $5 \%$.
TABEL IV

T-TEST PADA METODE PREPROCESSING STS DAN SST

\begin{tabular}{|c|c|c|}
\hline $\begin{array}{l}\text { Percobaan } \\
\text { ke }\end{array}$ & $\begin{array}{c}\text { Standar Deviasi } \\
\text { STS }\end{array}$ & $\begin{array}{c}\text { Standar Deviasi } \\
\text { SST }\end{array}$ \\
\hline 1 & 0.113200 & 0.114586 \\
\hline 2 & 0.122843 & 0.133375 \\
\hline 3 & 0.127292 & 0.128744 \\
\hline 4 & 0.128570 & 0.131216 \\
\hline 5 & 0.122292 & 0.123959 \\
\hline 6 & 0.129229 & 0.130659 \\
\hline 7 & 0.090304 & 0.093963 \\
\hline 8 & 0.110409 & 0.113629 \\
\hline 9 & 0.129395 & 0.132632 \\
\hline 10 & 0.112983 & 0.113571 \\
\hline 11 & 0.138067 & 0.137637 \\
\hline 12 & 0.125985 & 0.124094 \\
\hline 13 & 0.124189 & 0.124446 \\
\hline 14 & 0.132236 & 0.135796 \\
\hline 15 & 0.127823 & 0.129422 \\
\hline 16 & 0.219121 & 0.207233 \\
\hline 17 & 0.163111 & 0.153698 \\
\hline 18 & 0.154109 & 0.151013 \\
\hline 19 & 0.105973 & 0.103665 \\
\hline 20 & 0.114740 & 0.120380 \\
\hline 21 & 0.100381 & 0.102598 \\
\hline Rata- rata & 0.128202 & 0.128872 \\
\hline T-test & \multicolumn{2}{|c|}{ 0.93097} \\
\hline Alpha & \multicolumn{2}{|c|}{0.05} \\
\hline
\end{tabular}

Berdasarkan Tabel IV, pengujian T-test menghasilkan pvalue sebesar 0.93097. Nilai tersebut lebih besar dari Alpha yang ditetapkan yaitu 0.05 . Oleh karena itu, perbedaan urutan penggabungan metode preprocessing Stemming dengan Stopword Removal tidak menghasilkan nilai yang signifikan. Sehingga, total nilai tertinggi standar deviasi metode STS dan SST, apabila digabungkan memiliki nilai total yang lebih besar daripada metode S. Kesimpulannya adalah, penggunaan gabungan metode preprocessing stopword removal dan stemming menghasilkan sebaran nilai similarity yang terbesar.

\section{Analisis Hasil Dengan Hipotesis Kedua}

Untuk melakukan eksperimen hipotesis kedua diuji dengan membandingkan hasil similarity pada 3 eksperimen. Hasil similarity per bab dibandingkan dengan hasil similarity full text dengan metode preprocessing stopword removal + stemming. Apabila nilai similarity pada per bab lebih besar daripada full text akan diberi tanda warna merah pada tabel V, VI, dan VII.

Tabel V menunjukkan nilai similarity M03 dengan yang lainnya. Total nilai perbandingan yang lebih besar dari Full text pada Chapter_1 sebanyak 11, Chapter_2 sebanyak 6, Chapter_3 sebanyak 5, Chapter_4 tidak ada, Chapter_5 sebanyak 10, dan Chapter_Conclusion sebanyak 7. 
TABEL V

PERBANDINGAN NILAi SIMILARITY M03 PADA EKSPERIMEN PERTAMA

\begin{tabular}{|c|c|c|c|c|c|c|c|}
\hline ID & $\begin{array}{c}\text { Chapter_1 } \\
(\boldsymbol{c o s} \boldsymbol{\theta})\end{array}$ & $\begin{array}{c}\text { Chapter_2 } \\
(\boldsymbol{c o s} \boldsymbol{\theta})\end{array}$ & $\begin{array}{c}\text { Chapter_3 } \\
(\boldsymbol{c o s} \boldsymbol{\theta})\end{array}$ & $\begin{array}{c}\text { Chapter_4 } \\
(\boldsymbol{c o s} \boldsymbol{\theta})\end{array}$ & $\begin{array}{c}\text { Chapter_5 } \\
(\boldsymbol{c o s} \boldsymbol{\theta})\end{array}$ & $\begin{array}{c}\text { Chapter_- } \\
\text { Conclusion } \\
(\boldsymbol{c o s} \boldsymbol{\theta})\end{array}$ & Full Text \\
\hline M01 & 0.311987 & 0.452193 & 0.419967 & 0.428059 & 0.606286 & 0.246161 & 0.568346 \\
\hline M02 & 0.400682 & 0.337463 & 0.466366 & 0.270798 & 0.600001 & 0.390934 & 0.529194 \\
\hline M04 & 0.539122 & 0.579108 & 0.416043 & 0.448489 & 0.662449 & 0.329244 & 0.555510 \\
\hline M05 & 0.670660 & 0.559378 & 0.570961 & 0.517071 & 0.576442 & 0.436025 & 0.632701 \\
\hline M06 & 0.442869 & 0.229232 & 0.374316 & 0.377869 & 0.615098 & 0.309211 & 0.533066 \\
\hline M07 & 0.642418 & 0.534071 & 0.590443 & 0.480036 & 0.692905 & 0.359955 & 0.702468 \\
\hline M08 & 0.612390 & 0.534627 & 0.530185 & 0.495354 & 0.626508 & 0.338260 & 0.603716 \\
\hline M09 & 0.565995 & 0.287333 & 0.450814 & 0.390917 & 0.678672 & 0.564004 & 0.537418 \\
\hline M10 & 0.377356 & 0.383099 & 0.346968 & 0.250974 & 0.632625 & 0.341576 & 0.486966 \\
\hline M11 & 0.546362 & 0.674784 & 0.516028 & 0.577989 & 0.532536 & 0.415033 & 0.625806 \\
\hline M12 & 0.520845 & 0.515697 & 0.363934 & 0.391881 & 0.683792 & 0.467415 & 0.520167 \\
\hline M13 & 0.312362 & 0.290016 & 0.283245 & 0.334616 & 0.551423 & 0.300251 & 0.401957 \\
\hline M14 & 0.393777 & 0.395514 & 0.414049 & 0.262385 & 0.151622 & 0.286171 & 0.477923 \\
\hline M15 & 0.303668 & 0.362375 & 0.273401 & 0.195656 & 0.040908 & 0.242944 & 0.209140 \\
\hline M16 & 0.383533 & 0.235917 & 0.292990 & 0.194462 & 0.061626 & 0.265771 & 0.257912 \\
\hline M17 & 0.461182 & 0.284382 & 0.507540 & 0.250554 & 0.405417 & 0.338987 & 0.421215 \\
\hline M18 & 0.357681 & 0.264515 & 0.399725 & 0.346614 & 0.204548 & 0.496564 & 0.457084 \\
\hline M19 & 0.380433 & 0.444686 & 0.310975 & 0.211634 & 0.118432 & 0.294105 & 0.320249 \\
\hline M20 & 0.446560 & 0.412944 & 0.404046 & 0.290069 & 0.183027 & 0.356285 & 0.377686 \\
\hline M21 & 0.641469 & 0.547065 & 0.531368 & 0.443973 & 0.532278 & 0.563587 & 0.594980 \\
\hline M22 & 0.372365 & 0.428631 & 0.386046 & 0.184445 & 0.407547 & 0.409355 & 0.349399 \\
\hline M23 & 0.431951 & 0.227861 & 0.470273 & 0.341903 & 0.384813 & 0.585328 & 0.569816 \\
\hline M24 & 0.387640 & 0.496662 & 0.436270 & 0.304016 & 0.349637 & 0.540798 & 0.510461 \\
\hline
\end{tabular}

TABEL VI

PERBANDINGAN NILAI SIMILARITY M11 PADA EKSPERIMEN KEDUA

\begin{tabular}{|c|c|c|c|c|c|c|c|}
\hline ID & $\begin{array}{c}\text { Chapter_1 }(\boldsymbol{c o s} \\
\boldsymbol{\theta})\end{array}$ & $\begin{array}{c}\text { Chapter_2 } \\
(\boldsymbol{c o s} \boldsymbol{\theta})\end{array}$ & $\begin{array}{c}\text { Chapter_3 } \\
(\boldsymbol{c o s} \boldsymbol{\theta})\end{array}$ & $\begin{array}{c}\text { Chapter_4 } \\
(\boldsymbol{c o s} \boldsymbol{\theta})\end{array}$ & $\begin{array}{c}\text { Chapter_5 } \\
(\boldsymbol{c o s} \boldsymbol{\theta})\end{array}$ & $\begin{array}{c}\text { Chapter_ } \\
\text { Conclusion } \\
(\boldsymbol{c o s} \boldsymbol{\theta})\end{array}$ & Full Text \\
\hline M01 & 0.248407 & 0.353756 & 0.399907 & 0.531619 & 0.386653 & 0.181448 & 0.471350 \\
\hline M02 & 0.368510 & 0.241044 & 0.395790 & 0.236049 & 0.462882 & 0.209359 & 0.491090 \\
\hline M03 & 0.659592 & 0.409007 & 0.492426 & 0.430747 & 0.605002 & 0.452099 & 0.647488 \\
\hline M04 & 0.546362 & 0.674784 & 0.516028 & 0.577989 & 0.532536 & 0.415033 & 0.625806 \\
\hline M05 & 0.651523 & 0.433100 & 0.563527 & 0.567907 & 0.450585 & 0.423065 & 0.636424 \\
\hline M06 & 0.394446 & 0.211366 & 0.353973 & 0.316832 & 0.403245 & 0.211779 & 0.435163 \\
\hline M07 & 0.610207 & 0.421385 & 0.605117 & 0.494678 & 0.549949 & 0.499345 & 0.643449 \\
\hline M08 & 0.628168 & 0.442857 & 0.696914 & 0.462762 & 0.682400 & 0.406736 & 0.739498 \\
\hline M09 & 0.540299 & 0.240846 & 0.404558 & 0.423341 & 0.354141 & 0.283112 & 0.514639 \\
\hline M10 & 0.457159 & 0.318565 & 0.419865 & 0.257153 & 0.311773 & 0.157424 & 0.515806 \\
\hline M12 & 0.389607 & 0.545413 & 0.628024 & 0.343894 & 0.520624 & 0.288091 & 0.690269 \\
\hline M13 & 0.303059 & 0.231657 & 0.309505 & 0.464581 & 0.401454 & 0.198085 & 0.395658 \\
\hline M14 & 0.424900 & 0.227589 & 0.439265 & 0.254382 & 0.133220 & 0.174617 & 0.465904 \\
\hline M15 & 0.317885 & 0.254774 & 0.346929 & 0.211003 & 0.036531 & 0.169039 & 0.240094 \\
\hline M16 & 0.369394 & 0.233367 & 0.315697 & 0.141942 & 0.106045 & 0.147316 & 0.286742 \\
\hline M17 & 0.396581 & 0.271961 & 0.415776 & 0.236125 & 0.333613 & 0.161368 & 0.406956 \\
\hline M18 & 0.321170 & 0.183685 & 0.531339 & 0.392898 & 0.178209 & 0.260387 & 0.548636 \\
\hline M19 & 0.326521 & 0.316528 & 0.415059 & 0.159840 & 0.181658 & 0.095364 & 0.429762 \\
\hline M20 & 0.421006 & 0.273305 & 0.424189 & 0.227338 & 0.445865 & 0.191798 & 0.511116 \\
\hline M21 & 0.617354 & 0.394568 & 0.573586 & 0.583260 & 0.433086 & 0.420313 & 0.676971 \\
\hline M22 & 0.371127 & 0.339284 & 0.489186 & 0.227755 & 0.289965 & 0.289499 & 0.388538 \\
\hline M23 & 0.430233 & 0.230406 & 0.612330 & 0.371076 & 0.359905 & 0.306237 & 0.657499 \\
\hline M24 & 0.391840 & 0.465353 & 0.624071 & 0.362993 & 0.428072 & 0.288606 & 0.605010 \\
\hline
\end{tabular}


Tabel VI menunjukkan nilai similarity M11 dengan yang lainnya. Total nilai perbandingan yang lebih besar dari full text pada Chapter_1 sebanyak 5, Chapter_2 sebanyak 2, Chapter_3 sebanyak 5, Chapter_4 sebanyak 2, Chapter_5 sebanyak 1, dan Chapter_Conclusion tidak ada.
Tabel VII menunjukkan nilai similarity M21 dengan yang lainnya. Total nilai perbandingan yang lebih besar dari full text pada Chapter_1 sebanyak 7, Chapter_2 sebanyak 4, Chapter_3 sebanyak 5, Chapter_4 sebanyak 0, Chapter_5 sebanyak 2, dan Chapter_Conclusion sebanyak 2.

TABEL VII

PERBANDINGAN NILAI SIMILARITY M21 PADA EKSPERIMEN KETIGA

\begin{tabular}{|c|c|c|c|c|c|c|c|}
\hline ID & $\begin{array}{c}\text { Chapter_1 } \\
(\cos \theta)\end{array}$ & $\begin{array}{c}\text { Chapter_2 } \\
(\cos \theta)\end{array}$ & $\begin{array}{c}\text { Chapter_3 } \\
(\cos \theta)\end{array}$ & $\begin{array}{c}\text { Chapter_4 } \\
(\cos \theta)\end{array}$ & $\begin{array}{c}\text { Chapter_5 } \\
(\cos \theta)\end{array}$ & $\begin{array}{l}\text { Chapter_- } \\
\text { Conclusion } \\
(\cos \theta)\end{array}$ & Full Text \\
\hline M01 & 0.296902 & 0.517097 & 0.397307 & 0.463084 & 0.489654 & 0.211099 & 0.497558 \\
\hline M02 & 0.397208 & 0.383622 & 0.466059 & 0.313865 & 0.563937 & 0.349812 & 0.558220 \\
\hline M03 & 0.645714 & 0.596102 & 0.584886 & 0.561744 & 0.519489 & 0.317286 & 0.703851 \\
\hline M04 & 0.641469 & 0.547065 & 0.531368 & 0.443973 & 0.532278 & 0.563587 & 0.594980 \\
\hline M05 & 0.619959 & 0.615600 & 0.679673 & 0.651185 & 0.458331 & 0.341693 & 0.710297 \\
\hline M06 & 0.427636 & 0.221232 & 0.348081 & 0.396646 & 0.433211 & 0.273085 & 0.464717 \\
\hline M07 & 0.575484 & 0.582641 & 0.738928 & 0.396877 & 0.476928 & 0.430956 & 0.656291 \\
\hline M08 & 0.745367 & 0.602764 & 0.676292 & 0.422351 & 0.501450 & 0.286848 & 0.717577 \\
\hline M09 & 0.559778 & 0.329393 & 0.332032 & 0.363938 & 0.430969 & 0.462762 & 0.453017 \\
\hline M10 & 0.482115 & 0.456539 & 0.340024 & 0.302858 & 0.358758 & 0.341531 & 0.507833 \\
\hline M11 & 0.617354 & 0.394568 & 0.573586 & 0.583260 & 0.433086 & 0.420313 & 0.676971 \\
\hline M12 & 0.541416 & 0.469734 & 0.572480 & 0.444924 & 0.462734 & 0.397909 & 0.665353 \\
\hline M13 & 0.254160 & 0.317087 & 0.251418 & 0.367391 & 0.442339 & 0.298440 & 0.383876 \\
\hline M14 & 0.445585 & 0.365517 & 0.390882 & 0.282868 & 0.128879 & 0.225165 & 0.470567 \\
\hline M15 & 0.335126 & 0.339487 & 0.316190 & 0.211051 & 0.031702 & 0.218896 & 0.266147 \\
\hline M16 & 0.377274 & 0.224417 & 0.311895 & 0.156239 & 0.077097 & 0.240796 & 0.306047 \\
\hline M17 & 0.427135 & 0.328459 & 0.503703 & 0.270301 & 0.384241 & 0.342894 & 0.474143 \\
\hline M18 & 0.377507 & 0.237501 & 0.439646 & 0.373065 & 0.194359 & 0.498128 & 0.534084 \\
\hline M19 & 0.337823 & 0.539055 & 0.432921 & 0.215518 & 0.155586 & 0.223425 & 0.466251 \\
\hline M20 & 0.495619 & 0.430694 & 0.436145 & 0.242740 & 0.287950 & 0.290565 & 0.491309 \\
\hline M22 & 0.374653 & 0.531698 & 0.409689 & 0.212581 & 0.288797 & 0.376409 & 0.369555 \\
\hline M23 & 0.536267 & 0.320317 & 0.522983 & 0.356440 & 0.447233 & 0.462335 & 0.615058 \\
\hline M24 & 0.471225 & 0.269697 & 0.509806 & 0.306861 & 0.441107 & 0.480101 & 0.581085 \\
\hline
\end{tabular}

TABEL VIII

Jumlah Dari Total Perbandingan Per Bab DENGAN FulL TEXT

\begin{tabular}{|c|c|c|c|c|c|c|}
\hline Eskperimen & Chapter_1 & Chapter_2 & Chapter_3 & Chapter_4 & Chapter_5 & $\begin{array}{c}\text { Chapter_ } \\
\text { Conclusion }\end{array}$ \\
\hline 1 & 11 & 6 & 5 & 0 & 10 & 7 \\
\hline 2 & 5 & 2 & 5 & 2 & 1 & 0 \\
\hline 3 & 7 & 4 & 5 & 0 & 2 & 2 \\
\hline Total & 23 & 12 & 15 & 2 & 13 & 9 \\
\hline
\end{tabular}

TABEL IX

RATA-RATA NILAI SIMILARITY PER BAB DENGAN FULL TEXT

\begin{tabular}{|c|c|c|c|c|c|c|c|}
\hline Eskperimen & $\begin{array}{l}\text { Chapter_1 } \\
(\cos \theta)\end{array}$ & $\begin{array}{l}\text { Chapter_2 } \\
\quad(\cos \theta)\end{array}$ & $\begin{array}{c}\text { Chapter_3 } \\
(\cos \theta)\end{array}$ & $\begin{array}{c}\text { Chapter_4 } \\
(\cos \theta)\end{array}$ & $\begin{array}{l}\text { Chapter_5 } \\
\quad(\cos \theta)\end{array}$ & $\begin{array}{l}\text { Chapter_- } \\
\text { Conclusion } \\
(\cos \theta)\end{array}$ & $\begin{array}{c}\text { Full Text } \\
\quad(\cos \theta)\end{array}$ \\
\hline 1 & 0.456665 & 0.412068 & 0.424172 & 0.347381 & 0.447765 & 0.385998 & 0.488834 \\
\hline 2 & 0.442841 & 0.335417 & 0.477090 & 0.359833 & 0.373366 & 0.270875 & 0.522777 \\
\hline 3 & 0.477512 & 0.418273 & 0.468087 & 0.362598 & 0.371309 & 0.350176 & 0.528904 \\
\hline Rata-rata & \multicolumn{6}{|c|}{0.398968} & 0.513505 \\
\hline
\end{tabular}


TABEL X

URUTAN KATA TERBANYAK DALAM SETIAP BAB

\begin{tabular}{|c|c|c|c|c|c|c|}
\hline No & Chapter_1 & Chapter_2 & Chapter_3 & Chapter_4 & Chapter_5 & $\begin{array}{c}\text { Chapter_ } \\
\text { Conclusion }\end{array}$ \\
\hline 1 & data & data & data & data & data & aplikasi \\
\hline 2 & bab & sistem & gambar & gambar & menampilkan & saran \\
\hline 3 & aplikasi & universitas & tabel & halaman & hasil & data \\
\hline 4 & sistem & $\begin{array}{c}\text { "nama } \\
\text { universitas" }\end{array}$ & menampilkan & tampilan & tabel & simpulan \\
\hline 5 & barang & proses & barang & barang & pengujian & sistem \\
\hline
\end{tabular}

Setelah nilai similarity dirata-ratakan menjadi seperti pada Tabel IX, dapat disimpulkan bahwa nilai similarity pada setiap bab lebih kecil dari nilai similarity full text. Oleh karena itu, penggunaan metode perbandingan per bab dapat menghasilkan nilai similarity yang lebih kecil dari full text.

Tabel VIII menunjukkan jumlah dari total perbandingan nilai similarity setiap bab yang lebih besar dengan nilai similarity full text. Nilai Chapter_4 memiliki total paling kecil dan memiliki perbedaan yang signifikan dengan nilai bab yang lain. Setelah ditelusuri dari data teks, Chapter_4 banyak mengandung kode program baik secara tertulis atau gambar. Perhitungan tingkat similarity kode program perlu dilakukan penelitian lebih lanjut. Penggunaan stopword dan stemming dalam penelitian ini dalam berbahasa Indonesia sedangkan kode program biasanya dibuat dalam Bahasa Inggris.

Untuk mencari tahu karakteristik setiap bab, dilakukan mapping kamus kata dengan jumlah teks. Berikut pada Tabel IX merupakan hasil mapping dengan 5 urutan kata terbanyak pada setiap bab.

Berdasarkan Tabel X, kata "data" dapat dianggap dengan kemunculan kata terbanyak pada laporan Tugas Akhir. Karena data laporan ini diambil dari sebuah universitas yang sama dengan program studi teknologi informasi, kata "data" menjadi karakteristik pada program studi tersebut.

Berikut merupakan analisis karakteristik dari setiap bab:

1) Chapter_1 dengan judul "Pendahuluan" memiliki karakteristik dalam pembahasan rencana pembuatan laporan. Kata "bab" menunjukan penjelasan bab pada laporan tersebut sehingga menjadi karakteristik Chapter_1.

2) Chapter_2 dengan judul "Kajian Teori" memiliki karakteristik dalam membahas teori yang akan digunakan. Namun, kemunculan kata "universitas" dan "nama universitas" tidak menunjukan karakteristik pada Chapter_2. Setelah penelusuran data, penggunaan algoritma OCR dapat membaca format laporan yang dibuat universitas seperti penulisan nama universitas pada Header atau Footer.

3) Chapter_3 dengan judul "Analisis dan Rancangan" memiliki karakteristik memiliki banyak penjelasan pada tabel, diagram, dan gambar. Kata "gambar" dan "tabel" menunjukan karakteristik pada bab tersebut.
4) Chapter_4 dengan judul "Implementasi" memiliki karakteristik dalam penjelasan pembuatan sebuah sistem. Setelah penelusuran data, kata "halaman" menunjukan karakteristik pada Chapter_4. Kata tersebut sering digunakan untuk menampilkan contoh halaman UI.

5) Chapter_5 dengan judul "Pengujian" memiliki karakteristik dalam penjelasan hasil penelitian. Kata "menampilkan", "hasil", "tabel", dan "pengujian" menunjukan karakteristik bab tersebut. Penggunaan kata "tabel" sering digunakan untuk penjelasan dalam tabel di laporan.

6) Chapter_Conclusion dengan judul "Kesimpulan dan Saran" memiliki karakteristik dalam penjelasan kesimpulan hasil penelitian dan saran pengembangan lebih lanjut. Kata "saran" dan "simpulan" menjadi karakteristik bab tersebut.

Penggunaan stopword dari library Sastrawi dibuat berdasarkan kata umum dari Bahasa Indonesia. Kata yang menjadi karakteristik dari sebuah bab di laporan dapat berpotensi menjadi stopword. Karena kemunculan kata karakteristik pada sebuah bab yang terlalu banyak dan memiliki value yang kecil terhadap konteks bab tersebut, dapat mengganggu hasil dari String Similarity. Oleh karena itu, untuk penyempurnaan penelitian ini, diperlukan analisis lebih lanjut terhadap kata karakteristik yang dapat menjadi stopword pada perbandingan similarity setiap bab.

\section{DISKUSI}

Dengan penggunaan metode per bab pada perbandingan nilai similarity dengan preprocessing dapat meneliti karakteristik dari setiap bab. Berdasarkan Gambar 7, penggunaan format / template pada sebuah bab dapat mempengaruhi nilai similarity.

Chapter_4 di laporan Tugas Akhir program studi Teknologi Informasi sering berisi kode program. Karena library yang digunakan untuk Bahasa Indonesia dan metode perbandingan yang dilakukan fokusnya pada teks dalam sebuah bab, nilai sebuah tabel, diagram, kode program, dan gambar dengan teks biasa disamakan nilainya. Untuk penelitian lebih lanjut, dapat melakukan klasifikasi pada kode program lalu melakukan integrasi dengan sistem deteksi plagiarisme pada kode program seperti yang dibuat 
oleh Sulistiani dan Karnalim [8].

Kegunaan dari sebuah Stopword Removal yaitu membuang kata umum dari sebuah teks. Kata umum yang dibuat oleh library Sastrawi ditujukan untuk penggunaan secara teks Bahasa Indonesia yang umum. Jika lebih dirinci, kata yang sering muncul pada program studi Teknologi Informasi dapat berpotensi menjadi Stopword seperti pada Tabel X.

\section{KESIMPULAN DAN SARAN}

\section{A. Kesimpulan}

Metode preprocessing Stemming dan Stopword Removal dapat menghasilkan nilai sebaran hasil similarity tertinggi pada algoritma Cosine Similarity. Hasil tersebut sesuai dengan hipotesis pertama, yaitu metode Preprocessing Stopword + Stemming menghasilkan sebaran nilai similarity $(\cos \theta)$ paling tinggi daripada metode tanpa Preprocessing, Stopword, dan Stemming. Urutan penggunaan metode preprocessing Stemming dan Stopword Removal tidak menghasilkan nilai perbedaan yang signifikan.

Hipotesis kedua yang dibuat pada penelitian ini, yaitu menggunakan metode perbandingan bab menghasilkan tingkat similarity lebih besar daripada full text, tidak sesuai dengan hasil yang didapatkan. Berdasarkan Tabel IX, nilai similarity pada per bab dapat menghasilkan nilai yang lebih kecil dari full text, sehingga nilai similarity per bab dapat menjadi pertimbangan dalam penentuan plagiarisme. Walaupun hipotesis kedua tidak sesuai, penggunaan metode perbandingan per bab dapat menghasilkan bahan rekomendasi yang lebih banyak daripada perbandingan full text.

Teks dari sebuah laporan Tugas Akhir dari program studi Teknologi Informasi dapat menunjukan karakteristik tertentu. Pada program studi Teknologi Informasi, kata "data" menjadi karakteristik pada program studi tersebut. Karakteristik pada setiap bab pada laporan Tugas Akhir program studi Teknologi Informasi dapat dilihat pada Tabel $\mathrm{X}$.

\section{B. Saran}

Berdasarkan penelitian yang telah dilakukan, terdapat beberapa saran untuk penelitian selanjutnya:

1) Dikarenakan format data laporan berupa pdf, teknik OCR untuk membuat pdf menjadi teks, tidak memiliki akurasi sebesar $100 \%$. Direkomendasikan menggunakan data berbentuk teks untuk menghasilkan hasil similarity yang lebih akurat.

2) Sistem yang dibuat pada penelitian ini hanya membandingkan teks saja, dapat dibuat deteksi kemiripan yang dapat mengklasifikasi gambar, tabel, kode program, dan diagram. Untuk kode program dapat dilakukan pengecekan similaritas seperti pada penelitian yang telah dibuat oleh Sulistiani dan Karnalim [8].
3) Kata yang menjadi karakteristik suatu bab pada laporan dapat menjadi bahan pertimbangan untuk menjadi stopword dalam perbandingan antar bab. Kata tersebut perlu dianalisis lebih lanjut mengenai potensi menjadi stopword.

\section{DAFTAR PUSTAKA}

[1] H. A. Maurer, F. Kappe \& B. Zaka, "Plagiarism-A-suervey," J. UCS, vol. 12, pp. 1050-1084, Jan. 2006.

[2] S.D. Blum, My Word!: Plagiarism and College Culture, Cornell University Press, 2009.

[3] J. Liddel, "A Comprehensive Definition of Plagiarism," Community \& Junior College, vol. 11, pp. 43-52, Mar. 2003.

[4] B. Leonard \& S. Hansun, "Text documents plagiarism detection using Rabin-Karp and Jaro-Winkler," Indonesian Journal of Electrical Engineering and Computer Science, vol. 5, pp. 462-471, Feb. 2017.

[5] N. Kang, A. Gelbukh \& S. Han, "PPChecker: Plagiarism Pattern Checkerin Document Copy Detection," International Conference on Text, Speech and Dialogue, 2006, vol. 4188, pp. 661-667.

[6] Z. A. Al-Khanjari, J. A. Fiaidhi, R. A. Al-Hinai and N. S. Kutti, "PlagDetect: A Java Programming Plagiarism Detection Plug-in," ACM Inroads, vol. 1, pp. 66-71, Des. 2010.

[7] W. G. S. Parwita, I. G. A. A. D. Indradewi \& I. N. S. W. Wijaya, "String Matching based Plagiarism Detection for Document in Bahasa Indonesia," 2019 5th International Conference on New Media Studies (CONMEDIA), 2019, pp. 54-58.

[8] L. Sulistiani \& O. Karnalim, "ES-Plag: Efficient and sensitive source code plagiarism detection," Computer Applications in Engineering Education, vol. 27, pp. 166-182, Sept. 2018.

[9] L. Graham-Matheson \& S. Starr, "Is it cheating or learning the craft of writing? Using Turnitin to helpstudents avoid plagiarism," Research in Learning Technology, vol. 21, pp. 1-13, Apr. 2013.

[10] (2000) The Turnitin website. [Online]. Tersedia: http://www. turnitin.org/

[11] T. Fudge, (2018) Percentage Threshold for Determining Plagiarism. [Online]. Tersedia: https://scalar.usc.edu/works/c2c-digitalmagazine-fall-2018--winter-2019/should-there-be-percentagethreshold-determining-plagiarism-academic-offense

[12] C. D. Manning, P. Raghavan \& H. Schütze, "The term vocabulary and postings lists," Introduction to information retrieval, Cambridge University Press, pp. 19-47, 2008.

[13] J. B. Lovins, "Development of a stemming algorithm," Mech. Transl. Comput. Linguistics, vol. 11, no. 1-2, pp. 22-31, 1968.

[14] F. Tala, "A study of stemming effects on information retrieval in Bahasa Indonesia," M.Sc thesis, Institute for Logic, Language and Computation, Armsterdam, Belanda, 2003.

[15] C. D. Manning, P. Raghavan \& H. Schutze, "Scoring, Term Weighting and the vector space model," Introduction to information retrieval, Cambridge University Press, pp. 109-134, 2008.

[16] J. Han, M. Kamber \& J. Pei, Data mining : concept and techniques, Elsevier, 2011

[17] T. Mardiana, T. B. Adji \& I. Hidayah, "Stemming Influence on Similarity Detection of Abstract," TELKOMNIKA, vol. 14, no. 1, pp. 219-227, 2016.

[18] M. Lee. (2001) Pytesseract PyPI. [Online]. Tersedia: https://pypi.org/project/pytesseract/.

[19] Scikit-learn. (2007) Sklearn cosine_similarity documentation. [Online]. Tersedia: https://scikitlearn.org/stable/modules/generated/sklearn.metrics.pairwise.cosine similarity.html.

[20] Scikit-learn. (2007) Sklearn CountVectorizer documentation. [Online]. Tersedia: https://scikitlearn.org/stable/modules/generated/sklearn.feature_extraction.text.C ountVectorizer.html.

[21] NLTK Project. (2001) Natural Language Toolkit - NLTK 3.5 documentation [Online]. Tersedia: https://www.nltk.org/. 
[22] A. Librian. (2013) High quality stemmer library for Indonesian

Language Bahasa [Online]. Tersedia: https://github.com/sastrawi/sastrawi.

[Online].

[23] M. Adriani, J. Asian, B. Nazief, S. Tahaghohi \& H. E. Williams, "Stemming Indonesian: A confix-stripping approach.," ACM Transactions on Asian Languages Information Processing, vol. 6, no. 4, 2007.
[24] Scikit-learn. (2007) Feature_extraction documentation. [Online] Tersedia: https://github.com/scikit-learn/scikitlearn/blob/0fb307bf3/sklearn/feature_extraction/text.py\#L1168.

[25] Scikit-learn. (2007) Metric pairwise documentation. [Online] Tersedia: https://github.com/scikit-learn/scikitlearn/blob/0fb307bf3/sklearn/metrics/pairwise.py\#L1144. 